\title{
COMPETENCES OF TEACHERS AND STUDENTS IN ICT
}

\section{Danka LUKÁČOVÁ}

\begin{abstract}
Improving the quality of education in universities is possible only if we know the contents of educational curricula, which are confronted with a real Graduate. Investigators KEGA are dealing with the role of the ability of teachers and students to use ICT in practice - as in teacher training, as well as teaching itself. The article presents the results of the research conducted by questionnaire.
\end{abstract}

Key words: teacher of technical subjects, undergraduate preparation, questionnaire, information communication technologies

\section{KOMPETENCIE UČITELOV A ŠTUDENTOV V OBLASTI IKT}

Resumé: Zvyšovanie kvality vzdelávania na univerzitách je možné len vtedy, ak poznáme edukačné obsahy študijných programov, ktoré konfrontujeme $\mathrm{s}$ reálnym uplatnením absolventov $\mathrm{v}$ praxi. Riešitelia úlohy KEGA sa v úlohe zaoberajú schopnost'ou učitel’ov a študentov využívat' IKT v praxi ako v príprave učitel'a, tak aj v samotnej výučbe. Článok prezentuje čast' výsledkov výskumu realizovaného pomocou dotazníka.

Klíčová slova: učitel' technických predmetov, pregraduálna príprava, dotazník, informačno komunikačné technológie

\section{1 Úvod}

Príprava učitel'ov technických predmetov na PF UKF v Nitre je rozdelená na jednotlivé, vzájomne integrujúce zložky: pedagogickopsychologický a sociálno-vedný základ, odborná príprava, didaktiky (všeobecné a odborové) a prax. Tieto zložky majú za úlohu naplnit' kompetencie budúcich učitel'ov tak, aby zodpovedali požiadavkám výskumu aj pedagogickej praxe. Pre učitel'ov technických predmetov to znamená naplánovat' ich prípravu tak, aby absolvent druhého stupňa vysokoškolského štúdia $\mathrm{v}$ odbore učitel'stvo profesijných predmetov a praktickej prípravy bol spôsobilý byt' učitel'om technických predmetov na ZS a odborných predmetov technického zamerania (predmetových skupín) prislúchajúcich jeho špecializácii na úrovni vyššieho sekundárneho vzdelávania (SOŠ a SOU). Absolvent má ovládat' obsah nosných disciplín svojej odborovej špecializácie, poznat' profesijné profily a činnosti v príslušnom odbore, ako aj širšie teoretické zázemie odboru. Okrem zvládnutia učitel'skej spôsobilosti (projektovania, realizácie a reflexie výučby $\mathrm{v}$ triede) má byt' schopný participovat' na vývoji metodických materiálov pre výučbu, ako aj na projektovaní príslušných úsekov celoživotného vzdelávania (napr. rekvalifikácie) dospelých. Absolvent má mat' taktiež primerané poznatky $\mathrm{z}$ metód výskumu a vývoja v didaktike svojho odboru.
$\mathrm{V}$ súčasnosti sa $\mathrm{v}$ súvislosti s profilom absolventa učitel'ského študijného programu hovorí väčšinou o kompetenciách učitel'a. Tomuto pojmu bola $\mathrm{v}$ ostatných rokoch v pedagogickej teórii i výskume venovaná vel'ká pozornost'. Švec (1999) definuje tri skupiny učitel'ských kompetencií, a to: kompetencie $\mathrm{k}$ výchove a vyučovaniu, kompetencie osobnostné a kompetencie rozvíjajúce osobnost' učitel'a. Profesijné kompetencie učitel'a vel'mi dobre definuje Vašutová (2007). Profesijný štandard považuje za základný rámec pre rôzne úrovne kvalifikácií a špecializácií, v ktorých sa môžu rozvijat' kompetencie učitel'a, ktoré obsahujú potrebné vedomosti, zručnosti, postoje a skúsenosti pre výkon učitel'ského povolania.

Pedagogický slovník (Průcha, Walterová, Mareš, 2003, s. 103-104) definuje kompetencie učitel'a ako súbor profesijných zručností a dispozícií, ktorými má byt' vybavený učitel', aby mohol efektivne vykonávat' svoje povolanie. Obvykle sú uvádzané ako hlavné kompetencie osobnostné a kompetencie profesijné. Osobnostné kompetencie zahŕňajú zodpovednost', tvorivost', schopnost' riešit' problémy, spolupracovat' $\mathrm{v}$ tíme, byt' sociálne vnímavý a reflektívny. Profesijné kompetencie sa vzt’ahujú $\mathrm{k}$ obsahovej zložke výkonu profesie (znalost' predmetu), ale dnes bývajú zdôrazňované zvlášt' komunikatívne, riadiace, diagnostické a iné kompetencie. 
Vel'mi dôležitú úlohu pri vytváraní profesijných kompetencií plní dôkladná sebareflexia. Petlák (2004) uvádza, že sebareflexia je vnútorný proces, na základe ktorého si jedinec uvedomuje svoje správanie, myslenie, názory a postoje. Považuje ju za neoddelitel'nú súčast' práce učitel'a, pretože má vplyv na optimalizáciu a zefektívňovanie výchovno - vzdelávacieho procesu.

\section{Doterajšie výskumy danej problematiky}

Skúmaním profesijných kompetencií učitel'ov technických predmetov sa zaoberala Horáčková (2011). Uvádza: Na základe výsledkov $z$ vyhodnotenia dotaznika sme zistili, že profesijné kompetencie použivania výpočtovej techniky nepatria medzi najlepšie hodnotené kompetencie. Sebareflexia ukázala, že vlastnú schopnost použivat' výpočtovú techniku respondenti UPVOV (Učitelia praktického vyučovania a odborného výcviku) hodnotia ako priemernú. Ako l'ahko nadpriemernú, hodnotia túto schopnost' respondenti UOP (Učitelia odborných predmetov). V tomto vyššom hodnoteni sa zrejme premieta u respondentov UOP už absolvované vysokoškolské štúdium, ktorého spôsob vedie študentov $k$ aktívnemu využivaniu výpočtovej techniky.(Horáčková, 2011, s. 84)

Úroveň pedagogických kompetencií hodnotila vo svojom výskume Čellárová (2010, s. 26): Cielom prieskumu bolo zistit', ako hodnotia úroveň svojich pedagogických kompetencii poslucháči posledného - tretieho ročnika učitel'stva praktickej prípravy. Prieskum uskutočnili začiatkom šk. roku 2009/2010 na vzorke 120 poslucháčov externého štúdia ucitel'stva praktickej pripravy FPV UMB $v$ Banskej Bystrici, z toho 54 mužov a 66 žien. Z kompetencii ako najkvalitnejšie osvojené hodnotili respondenti vlastnú odbornú pripravenost' nadobudnutú štúdiom na strednej škole, schopnosti objektivne hodnotit' vlastné dispozicie, schopnosti vhodne komunikovat a využivat' $v$ sebarozvoji IKT. Za najlepšie osvojené označili respondenti vedomosti o nemateriálnych didaktických prostriedkoch (28,33\% hodnotili ako výborné, 36,67\% ako vel'mi dobré, $25 \%$ ako dobré, 9,17\% ako dostatočné a $0,83 \%$ ako nedostatočné). Prinajmenej prekvapivé bolo zistenie, že najmenej sú schopni navrhnút' a vytvorit' moderné učebné pomôcky $(24,17 \%$ respondentov hodnotilo ako výborné, 28,33\% ako vel'mi dobré, $28,33 \%$ ako dobré, $15 \%$ ako dostatočné a 4,17 \% ako nedostatočné).
Ukazuje sa, že respondenti v uvedených výskumoch hodnotia ako najlepšie svoje kompetencie vzt'ahujúce sa k odbornej zdatnosti, komunikačné kompetencie a kompetencie uplatnenie IKT v sebarozvoji. Takisto z výsledkov vidiet', že niektoré kompetencie inak hodnotia učitelia $z$ praxe a inak študenti učitel'stva. Podobným výskumom sa zaoberal tím pracovníkov na Pedagogickej fakulte UKF v Nitre, ktorý sa zaoberal kompetenciami učitel'ov pre technické odborné predmety.

\section{Ciele a metodika výskumu}

Výskum bol súčast'ou riešenia výskumnej úlohy KEGA 173-018UKF-4/2010 Overenie videokonferenčného systému a dištančných technológií $\quad \mathrm{v}$ aplikáciách. V súvislosti so zistovaním spôsobilosti uplatňovania videokonferenčných systémov a dištančných technológií na základných školách učitel'mi sme zistovali postoje a názory študentov učitel'stva technických predmetov na Pedagogickej fakulte a učitel'ov technických predmetov v praxi. Výskum bol realizovaný v rokoch 2010 - 2011.

$\mathrm{Na}$ zistenie súčasného stavu celoživotného vzdelávania učitel'ov s ohl'adom na ich schopnost' pracovat' $\mathrm{s}$ videokonferenčným systémom a multimediálnymi technológiami na Slovensku a v krajinách EÚ sme vypracovali dotazník zameraný na kompetencie učitel'ov vzhl'adom $\mathrm{k}$ ich profesii - špecificky na pedagogickú prax a videokonferenčné systémy, nakol'ko $\mathrm{v}$ tomto smere predpokladáme uplatnenie e-learningových metód v príprave učitel'ov.

Ciel'om výskumu bolo zistit':

1. stav prípravy učitel'ov $\mathrm{v}$ pregraduálnom vzdelávaní,

2. odbornú a metodickú zdatnost' učitel'ov smerom $\mathrm{k}$ tvorbe nových výučbových materiálov,

3. ako vnímajú učitelia možnosti videokonferenčných a ostatných e-learningových systémov $\mathrm{v}$ ich uplatnení $\mathrm{v}$ praxi a d’alšom vzdelávaní učitel'ov,

4. technické zázemie škôl s možnost'ou využívania videokonferenčných systémov vo výučbe žiakov, resp. študentov univerzít.

Vzhl'adom na stanovené ciele výskumu boli vypracované dva dotazníky - dotazník pre študentov učitel'stva (obsahuje všetky uvedené body) a dotazníka pre učitel'ov z praxe (obsahuje body 1 a 3 ).

Dotazník obsahoval 52 položiek. Obsah dotazníka tvorili 4 identifikačné položky, 10 položiek zameraných na technické vybavenie školy (1. dimenzia), 10 položiek zameraných na 
využívanie IKT v edukácii (pregraduálne štúdium) (2. dimenzia), 12 položiek zameraných konkrétne na videokonferencie - pojem, možnosti využitia $\mathrm{v}$ príprave na univerzitách a v učitel'skej praxi (3. dimenzia), 15 položiek skúmajúcich d’alšie vzdelávanie učitel'ov - obsah a formy (4. dimenzia).

Dotazník pre učitel'ov bol v elektronickej forme zadávaný učitel'om cez EduTech Portal webovú lokalitu spravovanú pracoviskom Katedra techniky a informačných technológií $\mathrm{PF}$ UKF v Nitre. Bolo oslovených 680 učitel'ov, dotazník vyplnilo 148 učitel'ov, čo je $22 \%$ - ná návratnost'. Na vyplnenie dotazníka pre študentov v tlačenej podobe bolo oslovených 38 študentov posledného ročníka magisterského štúdia učitel'ského študijného programu so zameraním na technické predmety, ktorí vyplnili dotazník. Štatistické spracovanie dotazníkov bolo uskutočnené v programe Excel.

\section{Výsledky výskumu}

Merným nástrojom pre prvú dimenziu bol dotazník s vol'bou odpovede. Ako merný nástroj pre 2., 3. a 4. dimenziu bol použitý Likertov škálovaný dotazník s 38 položkami. Všetky výroky boli definované iba pozitívne. Respondent sa mohol priklonit' $\mathrm{k}$ jednej $\mathrm{z}$ piatich ponúkaných možností od „úplne nesúhlasím“ (1 bod) po „úplne súhlasím“ (5 bodov). Neutrálna odpoved” „neviem“ bola hodnotená počtom bodov 0. Respondenti neboli pri vyplňovaní dotazníka časovo obmedzovaní.

Základné štatistické charakteristiky dimenzií 2, 3 a 4 (počet položiek - n, priemerné skóre $\bar{x}$, štandardnú chybu SD a rozptyl $s^{2}$ ) uvádzame $\mathrm{v}$ tabul'ke 1 .

Tabul'ka 1 Základné štatistiky dimenzií 2, 3, 4

\begin{tabular}{|l|l|c|c|c|}
\hline Dimenzia & $\mathrm{n}$ & $x$ & $\mathrm{SD}$ & $s^{2}$ \\
\hline $\begin{array}{l}\text { dimenzia } \\
2\end{array}$ & 10 & 2,73 & 0,86 & 0,74 \\
\hline $\begin{array}{l}\text { dimenzia } \\
3\end{array}$ & 15 & 2,44 & 0,68 & 0,46 \\
\hline $\begin{array}{l}\text { dimenzia } \\
4\end{array}$ & 13 & 2,68 & 0,58 & 0,36 \\
\hline
\end{tabular}

Výsledky prvej dimenzie:

- skoro $50 \%$ škôl nemá web kameru, alebo mikrofón.

- pripojenie väčšiny škôl k sieti Internet je na využivanie videokonferenčného systému nedostačujúce,
- približne 50 \% škôl nesplña minimálne technické požiadavky potrebné na zabezpečenie úspešného využivania moderných videokonferenčných systémov v pedagogickej praxi.(Šebo, 2011, s. 24)

Celkovým zhodnotením druhej dimenzie môžeme konštatovat' nasledovné:

učitelia hodnotia svoju odbornú prípravu v pregraduálnom štúdiu ako dostatočnú pre prax (čo sa týka odborných vedomostí a zručností),

rozsah náčuvovej, výstupovej a súvislej praxe považujú učitelia za dostatočný, privítali by však rozšírenie súvislej praxe,

zručnosti učitel'ov z oblasti využívania IKT sú na vel'mi dobrej úrovni, ale na ich praktické využitie $\mathrm{v}$ oblasti tvorby vyučovacích pomôcok sa necítia dostatočne pripravení.

Zhodnotenie tretej dimenzie:

- najvyšši postoj (v priemere 3,3) zaujali respondenti na položky 44 - vo výučbe využivam výpočtovú techniku a $47-v$ minulosti som sa už zúčastnil d'alšieho vzdelávania. (Bánesz, 2011, s. 366) Respondenti - učitelia z praxe využívajú vo výučbe výpočtovú techniku. $\mathrm{V}$ minulosti sa zúčastnili aspoň raz d'alšieho vzdelávania.

trom otázkam zodpovedá priemer 3,2. Konkrétne položke 40 - vedomosti z odboru si pravidelne aktualizujem, študujem odbornú literatúru, 41 - nové poznatky $z$ odboru transformujem do obsahu predmetu výučby a 42 vytváram si vlastné výučbové materiály. (tamtiež) Učitelia si teda vedomosti aktualizujú, študujú odbornú literatúru a nové poznatky transformujú do obsahu výučby. Tiež sa snažia vytvárat' vlastné výučbové materiály.

výrazne negatívny postoj zaujali respondenti na položku 52 - som ochotný zúčastnit' sa d'alšieho vzdelávania za finančnú úhradu. Platit' si za d'alšie vzdelávanie je ochotných len 34 respondentov (úplne súhlasim, skôr súhlasim) z celkového počtu 148.(tamtiež)

Učitelia sú naklonení d’alšiemu vzdelávaniu, avšak nie sú ochotní podiel'at' sa na jeho financovaní.

Závery $\mathrm{z}$ vyhodnotenia štvrtej dimenzie dotazníka:

učitelia poznajú význam videokonferencii $v$ školskej praxi, ale nedisponujú potrebnými vedomostami a zručnostami pre ich efektívne zarad'ovanie do výučby na základných školách,

doteraz sa osobne videokonferencii zúčastnili len respondenti, ktorí v školstve pracujú najviac osem rokov,

- aby boli videokonferenčné systémy naozaj zaradené medzi inovačné prvky vo 
vzdelávani žiakov, je potrebné zaradit' problematiku VRVS do obsahu vzdelávania učitel'ov v pregraduálnom a aj v postgraduálnom vzdelávaní.(Tomková, 2011, s.177)

\section{Záver}

Uvedené závery predpokladáme zapracovat' do podkladov pre prípravu učitel'ských študijných programov pre predmet technika na Pedagogickej fakulte UKF v Nitre nasledovne:

- zaradením predmetov orientovaných na tvorbu vyučovacích pomôcok pomocou IKT, čím predpokladáme posilnenie kompetencií učitel'ov technických predmetov v tomto smere.

- súvislú prax budúcich učitel'ov plánujeme posilnit' $\mathrm{v}$ rámci predmetu didaktika techniky uskutočňovaním videokonferenčných výstupových hodín spojených s rozborom vyučovacej hodiny online, ako aj súborom videozáznamov zo vzorových vyučovacích hodín umiestnených na školskej vzdelávacej lokalite.

Inováciou študijných programov vychádzajúcou $\quad \mathrm{z}$ výsledkov výskumu zameraného na štúdium požiadaviek pedagogickej praxe, predpokladáme skvalitnenie prípravy učitel'ov technických predmetov, čo sa, ako dúfame, odrazí aj v kvalitnejšej výučbe na základných školách a záujme žiakov o predmet technika.

Článok vyšiel ako výstup riešenia projektu KEGA 173-018UKF-4/2010 Overenie videokonferenčného systému a dištančných technológií v aplikáciách.

\section{Literatúra}

[1] BÁNESZ, G. Názory učitel'ov na využívanie IKT a možnosti d’alšieho vzdelávania. In: Trendy ve vzdělávání. Olomouc: UP, 2011, s. 366, ISBN 978-80-86768-34-2.

[2] ČELLÁROVÁ, L. Profesijné kompetencie začínajúceho majstra odbornej výchovy a ich reflexia. In: Journal of Technology and Information Education. Olomouc: UP, 2/2010, Volume 2, Issue 2, s. 26. ISSN 1803-537X

[3] HORÁČKOVÁ, M. Budoucí učitelé středních odborních škol a jejich sebereflexe u vybraných profesních kompetencí. In: Nové technologie ve vzdělávání. Olomouc: UP, 2011. s. 84. ISBN 978-80-244-2720-1

[4] PETLÁK, E., HUPKOVÁ, M. Sebareflexia a kompetencie $v$ práci učitel'a. Bratislava: Iris, 2004. ISBN 80-89018-77-7.

[5] PRŮCHA, J., WALTEROVÁ, E., MAREŠ, J. Pedagogický slovnik. 4., aktualizované vydání. Praha: Portál, 2003

[6] ŠEBO, M. Možnosti využitia videokonferenčných systémov na ZŠ z hl'adiska technickej infraštruktúry. In Journal of Technology and Information Education. Olomouc: Univerzita Palackého, roč. 3, č. 1, s. 22 -25. ISSN 1803-537X

[7] ŠVEC, V. Pedagogická př́prava budoucích učitelü: problémy,inspirace. Brno: Paido, 1999. 163 s. ISBN: 80-85931-70-2.

[8] TOMKOVÁ, V. Videokonferenčný systém ako inovačný prvok vo vzdelávaní In: Edukacja - Technika - Informatyka : wybrane problemy edukacji informatycznej $i$ informacyjnej. ISSN 2080-9069, Roč. 3, č. 2 (2011), 2. čast', s. 173178.

[9] VAŠUTOVÁ, J. Být učitelem. Praha : Univerzita Karlova v Prahe, Pedagogická fakulta, 2007. ISBN 978-80-7290-325-2

doc. PaedDr. Danka Lukáčová, PhD.

Katedra techniky a informačných technológií

Pedagogická fakulty UKF

Dražovská 4

94974 Nitra, SR

e-mail: dlukacova@ukf.sk 